\title{
The Effect of Tax Audit, Tax Billing, and Tax Sanctions on Value Added Tax Revenues (Survey on KPP in Bandung City Registered at the Regional Office of DJP West Java I for the 2015-2019 Period)
}

\author{
Rima Fitriyani* and N. Heryah
}

\begin{abstract}
Department of Economics and Business, Universitas Informatika dan Bisnis Indonesia, Bandung, Indonesia *Corresponding author.Email: rimafitriyani73@gmail.com
\end{abstract}

\begin{abstract}
This study aims to explore the factors that can affect value added tax revenue at KPP in Bandung City with time measurements from 2015-2019. The variables in this study consist of tax audit, tax billing, and tax sanctions as independent variables, and value added tax revenue as the dependent variable. The population in this study were KPPs in the city of Bandung, with a total sample of 2 KPP, namely KPP Pratama Bandung Tegallega and KPP Pratama Bandung Cicadas which were taken according to the research criteria determined by the purposive sampling method. The data testing technique was carried out using descriptive and verification methods, with classical assumption testing, multiple linear regression tests, determination coefficient test, multiple correlation coefficient test, and hypothesis testing. Individual research results indicate that tax audit has a positive and insignificant effect on value added tax revenue, tax billing has a negative and insignificant effect on value added tax revenue, and tax sanctions have a positive and insignificant effect on value added tax revenue. And the results of the research together show that the tax audit, tax billing, and tax sanctions have no effect on the value added tax receipts at the two KPPs registered at the Regional Office of the DJP West Java Indonesia for the 2015-2019 period.
\end{abstract}

Keywords: Tax audit, Tax billing, Tax sanctions, Value added tax

\section{INTRODUCTION}

A country certainly needs income, income that is used to finance expenses, both expenditure and expenditure [1]. A country has a relatively large need for funds to run the wheels of government, so the government tends to optimize stable sources of state revenue from the people themselves. One of the efforts to realize the independence of a nation or state in financing development, one of which is the source of funds originating from domestic taxes. Taxes are a means of achieving the goals of the state, namely realizing a just and prosperous society, and a means of mobilizing resources derived from community economic activities to finance national development.

The increase in tax revenue from year to year shows that there is great potential in the taxation sector, this increase in tax revenue will certainly increase state revenue [2]. Taxes are state income obtained from the people, and is the most important source that provides income to the state [3]. Taxes are used to finance state households, namely expenses that are beneficial to society [4].

According to law no. 17 of 2003 concerning state finances, tax revenues are all revenues consisting of domestic taxes and international trade taxes. Domestic taxes are all revenues originating from Income Tax $(\mathrm{PPh})$, Value Added Tax (PPN), Sales Tax on Luxury Goods (PPnBM), Land and Building Tax (PBB), Customs for Acquiring Land and Building Rights (BPHTB), Excise and others. International trade taxes are all revenues originating from import duties and export taxes. Therefore, the taxation sector must be optimized in such a way that it can support national expenditure or development in a country. 
Based on data sourced from the Central Statistics Agency (Ministry of Finance), it can be seen that one of the revenues in the taxation sector that has a high contribution is value added tax (PPN) as the second highest source of tax revenue after income tax $(\mathrm{PPh})$. Value added tax with the second highest position, has an average achievement of 489.341 billion rupiah. The achievement of value added tax revenue was very volatile in 2015-2019, the highest revenue occurred in 2019, which was 592.790 billion rupiah and the lowest was in 2016, which was 412.212 billion rupiah. Even though it is fluctuating, the achievement of this value added tax revenue has increased from year to year (Central Bureau of Statistics, Ministry of Finance). Value added tax is a substitute for sales tax, the reason for this replacement is because sales tax is deemed no longer adequate to support community activities and has not reached the target development needs, among others to increase state revenue, encourage exports and equalize tax imposition [5].

In terms of growth in domestic value added tax (VAT) for the 2014-2018 period, it experienced a slowdown, which only grew $8.94 \%$ lower than the previous year which was able to grow $12.97 \%$, this happened because the strengthening of import VAT resulted in the amount of tax credit for VAT domestic value increases (import VAT is a domestic VAT tax credit) so that in the end domestic VAT deposits slow down; increase in tax refunds in line with the short-term impact on the program to achieve restitution; and slowing retail sales, the results of the Retail Sales Survey (SPE) of Bank Indonesia indicate that retail sales are expected to grow by $4.6 \%$, slower than the previous year of $4.9 \%$, although it is higher than the previous year's $4.4 \%$.

Based on data taken from the West Java I Regional Tax Office, the overall target and realization of value added tax revenue has increased every year, but there are still revenues that have not been able to reach the predetermined targets so that the achievement of revenue cannot be done. maintained with the target set. such as data from the Ministry of Finance, where value added tax has decreased, this has also occurred at the West Java I Regional Tax Office, where from these data it can be seen that the phenomenon of the percentage of value added tax revenue achievement in 2015-2019 fluctuates greatly in KPPS registered at the Regional Office of the DJP Java. West. The highest percentage of income achievement occurred in 2017, the percentage of achievement exceeded the target of $114.29 \%$ where the target set was 9.289.391.773.000 and the realization exceeded the target set of 10.616.538.018.432 but declined again in the following year. And the lowest achievement occurred in 2015 , the percentage of achievement was only $81.41 \%$ where the realization was only $8,696,985,495,046$ and the revenue target of $10,683,255,311,000$ was still far from the target set (Kanwil DJP West Java I). Revenue attainment is still far from the target set although the percentage of achievement each year is more than $80 \%$, the unrealized target is caused by many factors that are difficult to avoid. These factors are not far from the compliance of taxpayers themselves in fulfilling their tax obligations.
Based on data from the Ministry of Finance and data from DGT West Java I which shows that value added tax revenue has decreased, data from KPP in the city of Bandung has experienced the same thing where value added tax revenue tends to decrease after experiencing an increase. Based on the processed data, the achievement of value added tax revenue as a whole has increased and decreased from year to year, and there are still revenues that have not been able to reach the predetermined target so that the achievement of these revenues. has not met the target set. From the data above, it can be seen that the phenomenon of the percentage of value added tax recipients' achievement during 2015-2019 fluctuated greatly in KPP Tegallega and KPP Cicadas. At Tegallega $\mathrm{KPP}$, the achievement that exceeded the target occurred in 2017 where the achievement was around $153 \%$, namely IDR. 686,256,661,237 and the lowest achievement occurred in 2015 where the achievement was around $88 \%$, namely IDR. 327,369,661,130 and in 2019 the lowest achievement was only around $86 \%$, namely $\mathrm{Rp}$. 910.647.262.698. At KPP Cicadas, the achievement that exceeded the target occurred in 2017 where the achievement was around $102 \%$, namely IDR. $712,630,661,264$ and the lowest achievement occurred in 2015 where the acquisition was around $80 \%$, namely IDR $574,045,621,194$ and in 2019 this achievement was in the range of $84 \%$, which is around IDR. 770,846,159,653 (KPP Tegallega and KPP Cicadas). The achievement that does not reach the target is caused by factors from the taxpayers themselves who are not obedient to their tax obligations, this is because many taxpayers themselves still do not understand and take tax avoidance measures.

One of the efforts made by the Directorate General of Taxes to increase tax revenues, namely by conducting tax audits and tax collection can create a sense of supervision and a deterrent effect for taxpayers who commit irregularities because they will be subject to tax sanctions. For the sake of creating taxation and order, tax sanctions are stipulated for tax violators.

Several previous studies have shown a relevant relationship between tax audits on value added tax revenue, such as research on ref [6], showing that tax audits have an effect on value added tax revenue. So, the higher the SKP issued in the audit will increase the amount of value added tax revenue. However, it is different from the results of research on ref [7], where the results state that the audit with the issuance of a tax assessment is still ineffective and has no effect on value added tax revenue.

Another previous study that showed a relevant relationship between tax billing and value added tax revenue, this study was conducted on ref [8], showing that tax collection has an effect on value added tax revenue. Another case with research on ref [9], where the results of their research show that tax billing by issuing forced letters has no effect on value added tax revenue.

Another previous research that shows a relevant relationship between tax sanctions on value added tax revenue, this study was conducted on ref [10], showing that tax sanctions have an effect on value added tax revenue. Another case with research conducted on ref [11], states 
that the imposition of sanctions by issuing tax bills has no effect on value added tax revenue.

Based on the description that has been presented, the researcher is interested in reexamining the value added tax revenue with the title "The Effect of Tax Audit, Tax billing and Tax Sanctions on Value Added Tax (PPN) Receipts (Survey on KPP in Bandung City which is registered at the Regional Office of the DJP Java. West I Period 20152019)".

\section{THEORETICAL STUDY}

\subsection{Theory of Planned Behaviour (TPB)}

Theory of Planned Behavior (TPB), this is a person's intention to carry out a behavior, where the intention is indicated by a person's desire to try or however much effort is made to carry out the behavior [12].

\subsection{Theory Attribution}

Attribution theory was developed by Fritz Heider who argued that a person's behavior is determined by a combination of internal forces, namely factors that come from within a person, such as ability or effort, and external forces, namely factors that are comes from outside, such as difficulties at work or luck [13].

\subsection{Value added tax}

Value added tax is a substitute for sales tax, the reason for this replacement is because sales tax is deemed no longer adequate to support community activities and has not reached the target development needs, among others to increase state revenue, encourage exports and equalize tax imposition [14].

\subsection{Tax audits}

Inspection is a series of activities to collect and process data, information, and / or evidence which are carried out objectively and professionally based on an inspection standard to test compliance with taxation obligations and / or for other purposes in implementing the provisions of tax laws and regulations [14].

\subsubsection{Tax Assessment Letter}

A tax assessment is an assessment letter which includes an underpayment tax assessment, an additional underpaid tax assessment, a zero tax assessment letter, or an overpayment tax assessment [14].

\subsection{Tax Billing}

Tax billing According to Law Number 19 Year 2000, the definition of tax billing is a series of actions taken by the tax directorate general so that tax bearers pay off tax debts and tax billing costs by admonishing / warning, collecting at once and at once, notifying a forced letter, proposing prevention, carry out confiscation, carry out hostagetaking, sell goods that have been confiscated [14]

\subsubsection{Force letter}

A force letter is issued if the tax collector does not pay off the tax debt and a letter of warning or warning or other similar letters is issued; to the tax bearer, the collection is carried out at once and at once; or the tax bearer does not fulfill the requirements as stated in the installment approval decision or tax payment postponement [14]

\subsection{Tax sanctions}

Tax sanctions guarantee that the provisions of the tax laws (taxation norms) will be obeyed / obeyed / obeyed or in other words, tax sanctions are a deterrent (preventative) so that taxpayers do not violate taxation norms [14]

\subsubsection{Tax Collection Letter}

A tax bill is a letter issued by the tax directorate general to carry out debt collection actions and / or administrative sanctions in the form of interest or fines [14]

\section{METHODOLOGY}

The object in this study is value added tax, and the variables that influence it are tax audits from published SKPKB, tax collection with forced letters, tax penalties with tax assessments, this research was conducted at KPP in Bandung City which is registered at the Regional Office of the DJP West Java I 2015-2019. The type of research method taken is quantitative research, called quantitative methods because the research data is in the form of numbers and the analysis uses statistics.

The population in this study population is KPP in Bandung City which is registered at the Regional Tax Office of West Java, and the samples in this study are 2 KPPs in Bandung City. tax collection by force letter, the incidence of the issuance of a tax bill and the incidence of the issuance of a value added tax revenue report in the data and information center section at the KPP in Bandung City which is registered with the Regional Office of the DJP West Java I for the period 2015-2019 200 (See Figure 1). 


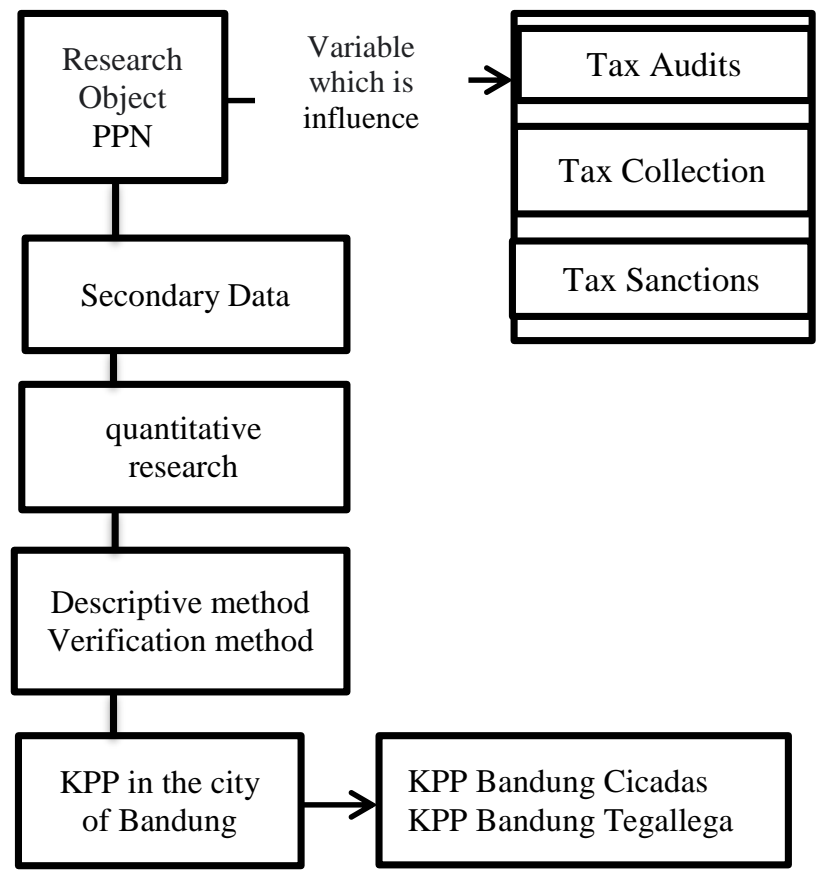

Figure 1 flow chart of the research

\section{RESULTS}

Based on the results of surveys in the field it is known that today millennia's dominate the creative business in Bengkulu city with an average of almost $80 \%$ of the 707 existing creative industries. The creators of this creative industry are average in the age of 20 to 40 years. A country will prosper if it has at least $2 \%$ entrepreneurs of the total population

The data is processed using the Statistical Package for Social Sciences (SPSS) application program version 26 for windows. In this study using descriptive and verification analysis, "the purpose of descriptive research is to make descriptions, pictures or paintings systematically, factually and accurately regarding facts, characteristics and relationships between the phenomena under study" [15]. And "verification research aims to determine the causality relationship between variables through hypothesis testing, through statistical calculations so that the evidentiary results show that the hypothesis is rejected or accepted" [15].

\subsection{Classic Assumption Testing}

\subsubsection{Normality Test}

Following are the results of the research on the Normality Test with the Komogorov-Smirnov (K-S) non-parametric statistical test, which can be seen in Table 1.
Table 1 Results of the One-Sample Kolmogorov-Smirnov Test

\begin{tabular}{lrr}
\hline & & Unstandardized Residual \\
\hline $\mathrm{N}$ & & 10 \\
Normal & -.0000732 & .0000005 \\
Parameters $^{\mathrm{a}, \mathrm{b}}$ & 1.531 & 39.869 \\
& .190 & .107 \\
Most Extreme & .180 & .106 \\
Differences & -.190 & -.107 \\
Test Statistic & & 190 \\
Asymp. Sig. (2-tailed) & & $.200^{\mathrm{c}, \mathrm{d}}$ \\
\hline
\end{tabular}

Based on the results of the SPSS output in Table using the One-Sample Kolmogorov-Smirnov Test, the Asymp value is obtained. Sig. Greater than 0.05 where the Asymp value. Sig. amounting to $0.200(0.200>0.05)$ so it can be concluded that the data is normally distributed and the hypothesis $\mathrm{H} 0$ is accepted, namely the residual data is normally distributed.

\subsubsection{Multicolonierity Test}

The following results of the Multicollinearity test can be seen in Table 2.

Table 2 Multicollinearity Test Results

\begin{tabular}{cccc}
\hline & Model & \multicolumn{2}{c}{ Collinearity Statistics } \\
\hline & & Tolerance & VIF \\
& & & \\
1 & X1_SKPKB & .123 & 8.153 \\
& X2_SP & .165 & 6.079 \\
& X3_STP & .427 & 2.343 \\
\hline
\end{tabular}

a. Dependent Variable: Y_PNN

Based on the SPPS output results in Table 2, it is known that the VIF value of the tax audit variable (X1_SKPKP) is 8.153, tax collection (X2_SP) is 6.079, and tax sanctions (X3_STP) are 2.323, because the VIF value for all these variables is $<10$ so that it can It was concluded that there was no multicolonierity disorder or in other words this regression model was free from multicolonierity symptoms.

\subsubsection{Heteroscedasticity Test}

The following Glejser test results can be seen in Table 3 . 
Table 3 Glejser Test Results

\begin{tabular}{|c|c|c|c|c|c|c|}
\hline & \multirow[t]{2}{*}{ Model } & \multicolumn{2}{|c|}{$\begin{array}{l}\text { Unstandardized } \\
\text { Coefficients }\end{array}$} & \multirow{2}{*}{$\begin{array}{c}\begin{array}{c}\text { Standardized } \\
\text { Coefficients }\end{array} \\
\text { Beta }\end{array}$} & \multirow[t]{2}{*}{$\mathrm{t}$} & \multirow[t]{2}{*}{ Sig. } \\
\hline & & B & $\begin{array}{l}\text { Std. } \\
\text { Error }\end{array}$ & & & \\
\hline & (Constant) & 1.849 & 7.301 & & 2.534 & .044 \\
\hline \multirow{3}{*}{1} & X1_SKPKB & -5.877 & 7.001 & -.818 & -.839 & .433 \\
\hline & X2_SP & 1.027 & 3.368 & .257 & .305 & .771 \\
\hline & X3_STP & 1.313 & 5.868 & .117 & .224 & .830 \\
\hline
\end{tabular}

a. Dependent Variable: ABRESID

Based on the results of the SPSS output in Table 3 above with the heteroscedasticity test using the Glajser test, the significance value of each variable is $0.433 ; 0.771 ; 0.830$ and the value is greater than 0.05 , so it can be concluded that the heteroscedasticity problem does not occur.

\subsubsection{Autocorrelation Test}

Following the run test, the test results can be seen in the Table 4.

Table 4.Test Runs Test

\begin{tabular}{lr}
\hline & Unstandardized Residual \\
\hline Test Value $^{\mathrm{a}}$ & 1.366 \\
Cases $<$ Test Value & 5 \\
Cases $>=$ Test Value & 5 \\
Total Cases & 10 \\
Number of Runs & 5 \\
Z & -.335 \\
Asymp. Sig. (2-tailed) & .737 \\
\hline
\end{tabular}

a. Median

Based on the results of the SPPS output in Table 4, the autocorrelation test using the runs test, the Asymp value is known. Sig. equal to 0.737 , greater than 0.05 , which is the basis for decision making if the value of Asymp. Sig. Greater than 0.05 , there is no autocorrelation symptom and vice versa. So it can be concluded that the autocorrelation problem that cannot be solved with Durbin Watson can be resolved through a run test with the result that there are no symptoms or autocorrelation problems because of the Asymp value. Sig. greater than 0.05 .

\subsection{Multiple linear regression analysis}

The regression analysis equation model in this study is multiple linear regression analysis, with the equation:

\section{$\mathrm{Y}=\alpha+\mathrm{b} 1 \mathrm{X} 1+\mathrm{b} 2 \mathrm{X} 2+\mathrm{b} 3 \mathrm{X} 3+\mathrm{e}$}

The following results from the multiple linear regression analysis tests can be seen in Table 5 .

Based on the SPPS output results in Table 5 above, it is obtained a constant value of 5.313 and a regression coefficient value for tax audits (X1_SKPKP) of 5.313; tax collection (X2_SP) of 6.109; (X3_STP) tax sanction of 1.847. From this value, the form of a multiple linear regression equation model is obtained as follows:

$$
\begin{gathered}
\mathrm{Y}=\mathrm{a}+\mathrm{b} 1 \mathrm{X} 1+\mathrm{b} 2 \mathrm{X} 2+\mathrm{b} 3 \mathrm{X} 3+\mathrm{e} \\
\mathrm{Y}=5313+10.725+(-6.109)+1.847+\mathrm{e}
\end{gathered}
$$

Based on the regression equation above, it can be informed as follows:

1. The constant value (a) is 5.313, this result shows that if X1_SKPKB (tax audit), X2_SP (tax collection), X3_STP (Tax Sanction) is 0, and then value added tax revenue $(\mathrm{Y})$ is 5.313 .

2. The regression coefficient value of the tax audit variable $(\mathrm{X} 1)$ is 10.725 ; this indicates that if the other independent variables are fixed and the tax audit has increased by one unit, the value added tax revenue (Y) will increase by 10.725 . The coefficient is positive, meaning that there is a positive relationship between tax audit and value added tax revenue, the higher the tax audit, the value added tax revenue will increase.

3. The regression coefficient value of the tax collection variable (X2) is -6.109 ; this indicates that if the other independent variables are constant and tax collection increases by one unit, the value added tax revenue (Y) will decrease by -6.109 . The coefficient is negative, meaning that there is a negative relationship between tax collection and value added tax revenue, the higher the tax collection, the lower the value added tax revenue. 
Table 5 Multiple linear regression analysis

\begin{tabular}{llccc}
\hline \multirow{2}{*}{ Model } & \multicolumn{2}{c}{$\begin{array}{c}\text { Unstandardized } \\
\text { Coefficients }\end{array}$} & $\begin{array}{c}\text { Standardized } \\
\text { Coefficients }\end{array}$ \\
\hline \multirow{2}{*}{} & & B & $\begin{array}{c}\text { Std. } \\
\text { Error }\end{array}$ & Beta \\
& (Constant) & 5.313 & 1.336 & \\
& X1_SKPKB & 10.725 & 12.814 & .829 \\
1 & X2_SP & -6.109 & 6.164 & -.848 \\
& X3_STP & 1.847 & 10.741 & .091 \\
\hline
\end{tabular}

a. Dependent Variable: Y_PNN

4. The regression coefficient value of the tax sanction variable (X3) is 1.847; this indicates that if the other independent variables are fixed and the tax sanction increases by one unit, the value added tax revenue $(\mathrm{Y})$ will increase by 1.847 . The coefficient is positive, meaning that there is a positive relationship between taxation sanctions and value added tax revenue, the higher the tax sanction, the higher the value added tax revenue.

\subsection{Correlation Coefficient}

The following results from the correlation coefficient test can be seen in Table 6 .

Table 6 Correlation Coefficient

\begin{tabular}{lc}
\hline Model & $\mathrm{R}$ \\
\hline 1 & $527^{\mathrm{a}}$ \\
\hline $\begin{array}{l}\text { a. Predictors: (Constant), X3_STP, X2_SP, X1_SKPKB } \\
\text { b. Dependent Variable: PNN }\end{array}$
\end{tabular}

Based on the results of the SPSS output in Table 6 above, it shows that the value of the multiple coefficients $(\mathrm{R})$ is 0.143 . This figure shows a correlation or relationship between tax audit variables, tax collection, tax sanctions on value added tax revenue. There is also a decision making strong or weak relationship between these variables based on the correlation coefficient interpretation table $0.40-0.599$, it can be concluded that the value of 0.527 is included in the moderate coefficient interval which means that the relationship between tax audits, tax collection, tax penalties on tax revenue has a level of relationship. moderate correlation coefficient.

\subsection{Analysis of the Coefficient of Determination}

The following results from the analysis of the coefficient of determination can be seen in Table 7 .

Table 7 Analysis of the Coefficient of Determination

\begin{tabular}{rlrr}
\hline Model & R & R Square & Adjusted R Square \\
\hline 1 & $.527^{\mathrm{a}}$ & .278 & -.083
\end{tabular}

a. Predictors: (Constant), X3_STP, X2_SP, X1_SKPKB

b. Dependent Variable: PNN

Based on the results of the SPSS output in Table 7, it is known that the coefficient of determination or $\mathrm{R}$ square is $0.27,8$. The $\mathrm{R}$ square value of 0.21 comes from the square of the correlation coefficient or $\mathrm{R}$, which is $0.527 \times 0.527=$ 0.278 . The amount of the coefficient of determination ( $\mathrm{R}$ Square) is 0.21 or equal to $21 \%$. This figure means that the tax audit variable, tax collection, tax sanctions simultaneously affect value added tax revenue by only $27.8 \%$. While the rest $(100 \%-27.8 \%=72.2 \%)$ is influenced by other variables outside of this regression equation or other variables not examined.

\subsection{Hypothesis Testing}

\subsubsection{T test}

The following results from the T Test can be seen in Table 8 . 
Table $8 \mathrm{~T}$ test

\begin{tabular}{|c|c|c|c|c|c|c|}
\hline & \multirow[t]{2}{*}{ Model } & \multicolumn{2}{|c|}{$\begin{array}{l}\text { Unstandardized } \\
\text { Coefficients }\end{array}$} & \multirow{2}{*}{$\begin{array}{c}\begin{array}{c}\text { Standardized } \\
\text { Coefficients }\end{array} \\
\text { Beta }\end{array}$} & \multirow[t]{2}{*}{$\mathrm{t}$} & \multirow[t]{2}{*}{ Sig. } \\
\hline & & B & $\begin{array}{l}\text { Std. } \\
\text { Error }\end{array}$ & & & \\
\hline & (Constant) & 5.314 & 1.337 & & 3.976 & .007 \\
\hline \multirow{3}{*}{1} & X1_SKPKB & 10.725 & 12.814 & .829 & .837 & .435 \\
\hline & X2_SP & -6.109 & 6.164 & -.848 & -.991 & .360 \\
\hline & X3_STP & 1.847 & 10.741 & .091 & .172 & .869 \\
\hline
\end{tabular}

a. Dependent Variable: Y_PNN

Based on the results of the SPSS output in Table 8, before making a conclusion from the T-test table the researcher formulates the T-Table value as follows:

1. It is known that the significance value ( $\mathrm{Sig}$ ) of the tax audit variable (X1_SKPKB) is 0.435 greater than 0.05 and the $t$ value is 0.837 less than the $t$ table value of 3.1426 , so it can be concluded that the first hypothesis is rejected, because the variable tax significance value audit is greater than 0.05 and the $\mathrm{t}$ count value is smaller than the $\mathrm{t}$ table value means there is no effect, another assumption is seen from the beta value which is 0.829 which means it has an effect of $82.9 \%$ This means that the individual tax audit (X1) has a positive and insignificant effect on value added tax $(\mathrm{Y})$.

2. It is known that the significance value (Sig) of the tax billing variable (X2_SP) is 0.360 greater than> 0.05 and the $t$ value of -0.991 is smaller than the $t$ table value of 3.1426 , so it can be concluded that the second hypothesis is rejected, because The significance value of the tax collection variable is greater than 0.05 and the calculated $t$ value is smaller than the t table value, meaning that there is no influence. Another assumption seen from the beta value is -0.848 or $-84.9 \%$ which means that tax billing (X2) has a negative and insignificant effect on value added tax revenue (Y).

3. It is known that the significance value (Sig) of the tax sanctions variable (X3_STP) of 0.869 is greater than 0.05 and the $t$ value of 0.172 is smaller than the $t$ table value of 3.1426 , so it can be concluded that the first value of the hypothesis is rejected, because of the significance value each variable is greater than 0.05 and the calculated $t$ value is smaller than the $t$ table value, meaning there is no effect. Another assumption is the beta value of 0.091 or $9.1 \%$, which means that taxation sanctions (X3) have a positive effect on value added tax revenue (Y).

\subsubsection{F Test}

The following results from the $\mathrm{F}$ Test can be seen in Table 9.
Table 9 F Test

\begin{tabular}{|c|c|c|c|c|c|c|}
\hline \multicolumn{2}{|c|}{ Model } & $\begin{array}{c}\text { Sum of } \\
\text { Squares }\end{array}$ & df & $\begin{array}{l}\text { Mean } \\
\text { Square }\end{array}$ & $\mathrm{F}$ & Sig. \\
\hline \multirow{3}{*}{1} & Regression & 8.121 & 3 & 27.070 & .770 & $.552^{\mathrm{b}}$ \\
\hline & Residual & 2.110 & 6 & 35.168 & & \\
\hline & Total & 2.922 & 9 & & & \\
\hline
\end{tabular}

a. Dependent Variable: Y_PNN

b. Predictors: (Constant), X3_STP, X2_SP, X1_SKPKB

Based on the results of the SPSS output in Table 9, before making a conclusion from the $\mathrm{F}$ test table the researcher formulates the $\mathrm{F}$ table value as follows After finding the $\mathrm{F}$ table value, it can be concluded that the significance value of 0.617 is greater than 0.05 and the calculated $F$ value is more than 0.600 small < from $F$ table of 2.71 , so that the tax audit variable, tax collection and tax sanctions do not affect simultaneously (together) on value added tax revenue.

\section{DISCUSSION}

\subsection{The effect of tax audit on value added tax revenue}

Based on the significance value (Sig) of the tax audit variable (X1_SKPKB) of 0.435 is greater than 0.05 and the $t$ value is 0.837 less than the $t$ table value of 3.1426 , so it can be concluded that the first hypothesis is rejected, because the significance of the tax audit variable is higher. greater than 0.05 and the calculated $t$ value is smaller than the $\mathrm{t}$ table value, meaning there is no effect. Another assumption is seen from the beta value which is 0.829 which means that it has an effect of $82.9 \%$. This means that individual tax audits (X1) have a positive and insignificant effect on value added tax $(\mathrm{Y})$. This shows that SKPKB revenues can increase VAT revenues, the higher the SKPKB value, the higher the VAT value. 


\subsection{Effect of tax billing on value added tax revenue}

Based on the significance value (Sig) of the tax collection variable (X2_SP) of 0.360 , it is greater than 0.05 and the $t$ value of -0.991 is smaller than the $t$ table value of 3.1426 , so it can be concluded that the second hypothesis. rejected, because the significance value of the tax audit variable is greater than 0.05 and the calculated $t$ value is smaller than the $\mathrm{t}$ table value, meaning that there is no influence. Another assumption seen from the beta value is -0.848 or $84.9 \%$ which means that tax collection (X2) has a negative and insignificant effect on value added tax revenue (Y). This shows that billing by issuing forced letters has not been able to increase value added tax revenue, this can be due to the fact that taxpayers have fulfilled their tax obligations at the time the tax bills are issued so there is no need for billing by forced letters so that forced issuance of letters does not increase tax revenues.

\subsection{Effect of Tax Sanctions on value added tax revenue}

Based on the significance value (Sig) of the tax sanction variable (X3_STP) of 0.869 , greater than 0.05 and the $t$ value of 0.172 is smaller than the t-table value of 3.1426 , so it can be concluded that the first hypothesis is rejected., because the significance value of each variable is greater than 0.05 and the calculated $t$ value is smaller than the $t$ table value, it means that there is no influence. Another assumption is the beta value of 0.091 or $9.1 \%$, which means that taxation sanctions (X3) have a positive effect on value added tax revenue (Y). This shows that tax sanctions by issuing dry taxes can increase value added tax revenue because the higher the value of the tax sanctions, the higher the VAT value.

\subsection{Effects of Tax Audit, tax billing and tax sanctions on value added tax revenue}

Based on the significance value of 0.552 , greater than 0.05 and the calculated $F$ value of 0.770 is smaller than the $F$ table of 4.76, so that the tax audit, tax collection and tax variables do not affect tax revenue simultaneously (together) value added. The results of this study state that together (simultaneously) the variables of tax audit, tax collection, and tax sanctions have an effect on value added tax revenue, and in fact the coefficient of determination ( $R$ Square) is 0.278 or equal to The same $27.8 \%$ figure means that the tax audit variable, tax collection, tax simultaneously affects the value added tax revenue by only $27.8 \%$. While the rest $(100 \%-27.8 \%=72.2 \%)$ other variables outside this regression equation or other variables that are not studied.

\section{CONCLUSION}

This study aims to determine how the effect partially and simultaneously between each of the variables tested, namely tax audits, tax collection, and tax sanctions on value added tax revenue at KPP Kota Bandung which is registered at the Regional Office of DJP West Java I for the 2015-2019 period. Based on the discussion that has been described in the previous chapter and the results of the tests that have been carried out using descriptive and verification methods, the following conclusions are obtained. Based on the research results indicate that the tax audit (X1) is: an individual has a positive effect on value added tax revenue (Y); Based on the research results, it shows that individual tax billing (X2) has a negative effect on value added tax revenue (Y); Based on the research results, it shows that individual tax sanctions (X3) have a positive effect on value added tax revenue (Y); Based on the results of the study, it shows that tax audit, tax billing and tax sanctions have no effect simultaneously (jointly) on value added tax revenue.

\section{REFERENCES}

[1] M. Siregar, N. Nagai, M. Suryadi. Secondary crops based farming systems and their integration with processing in Lampung, Indonesia (No. 1438-2016118958) 2006. DOI: https://doi.org/10.22004/ag.econ. 96622

[2] T. Andreyeva, F. J. Chaloupka, K. D. Brownell. Estimating the potential of taxes on sugar-sweetened beverages to reduce consumption and generate revenue. Preventive medicine, 52 (6) (2011) 413-416. DOI : https://doi.org/10.1016/j.ypmed.2011.03.013

[3] E. Saez, J. Slemrod, S. H. Giertz. The elasticity of taxable income with respect to marginal tax rates: A critical review. Journal of economic literature, 50 (1) (2012) 3-50. DOI: https://doi.org/10.1257/jel.50.1.3

[4] E. S. Lieberman. Taxation data as indicators of state-society relations: Possibilities and pitfalls in crossnational research. Studies in Comparative International Development, 36(4) (2002) 89-115.

[5] N. K. Kami, C. R. Rantelangi, R. P. Utomo. Perhtiungan, Pemungutan, dan Pelaporan Pajak PPh 21 Karyawan (Studi Kasus Pada PDAM Tirta Alam Tarakan. Jurnal Ilmu Akuntansi Mulawarman (JIAM), 4 (3) 2020 60-9. DOI : http://dx.doi.org/10.29264/jiam. v4i3.4958

[6] S. Mispa. Pengaruh Kualitas Pelayanan dan Kompetensi Fiskus Terhadap Kepuasan Wajib Pajak. 
Tangible Journal, 3 (2) (2018) 155-168. DOI: https:// doi. org/10.47221/tangible.v3i2.21

[7] T. Kiow, M. F. M. Salleh, A. A. B. M. Kassim. The determinants of individual taxpayers' tax compliance behaviour in peninsular malaysia. International Business and Accounting Research Journal, 1 (1) (2017) 26-43. DOI: http://dx.doi.org/10.15294/ibarj.v1 i1.4

[8] A. Yamazaki. Jobs and climate policy: Evidence from British Columbia's revenue-neutral carbon tax. Journal of Environmental Economics and Management, 83 (2017) 197-216. DOI : https://doi.org/ 10.1016/j.jeem.2017.03.003

[9] S. Siami-Namini, D. Muhamma, F. Fahimullah. The Short and Long Run Effects of Selected Variables on Tax Revenue-A Case Study. Applied Economics and Finance, 5 (5) (2018) 23-32. DOI : https://doi.org/10.11 114/aef.v5i5.3507

[10] E. N. Fadzilah, R. M. Mustaf, N. K. Putri. The Effect of Tax Understanding, Tax Payness Consciousness, Quality of Tax Service, and Tax Sanctions on Compulsory Tax of SMEs In Banyumas. Acta Universitatis Danubius. Economica, 13 (4) (2017) 115-160.

[11] K. D. Martin. Monetary myopia: An examination of institutional response to revenue from monetary sanctions for misdemeanors. Criminal Justice Policy Review, 29 (6-7) (2018) 630-662. DOI: https://doi.org $/ 10.1177 / 0887403418761099$

[12] C. Oztekin, G. Teksöz, S. Pamuk, E. Sahin, D. S. Kilic. Gender perspective on the factors predicting recycling behavior: Implications from the theory of planned behavior. Waste Management, 62 (2017) 290302. DOI: https://doi.org/10.1016/j.wasman.2016.12.0 36

[13] C. Mangiwa, A. Bandang, H. Ridwan, M. Ashari, M. T. Lobo. The Effect of Locus of Control, Time Budget Pressure, and Professional Commitment on Dysfunctional Audit Behaviour. Journal of Education and Vocational Research, 8(2) (2017) 49-61. DOI: https://doi.org/10.22610/jevr.v8i2.1862

[14] Mardiasmo, Perpajakan, Yogyakarta: Andi Publisher 2019.
[15] A. Pasinringi, M. N. Alamsyah, M. A. Samad. Measuring the Level of Discipline of Bureaucrats in Palu City. International Journal of Multicultural and Multireligious Understanding, 7 (10) (2020) 79-86. DOI: http://dx.doi.org/10.18415/ijmmu.v7i10.2011 